\title{
Experimental Coinfection with Aquabirnavirus and Viral Hemorrhagic Septicemia Virus (VHSV), Edwardsiella tarda or Streptococcus iniae in Japanese Flounder Paralichthys olivaceus
}

\author{
Rolando Pakingking Jr. ${ }^{1}$, Ryoko Takano ${ }^{1}$, Toyohiko Nishizawa ${ }^{2}$, Koh-ichiro Mori ${ }^{3}$, \\ Yoshisuke lida ${ }^{4}$, Misao Arimoto ${ }^{3}$ and Kiyokuni Muroga ${ }^{1 *}$ \\ ${ }^{1}$ Graduate School of Biosphere Sciences, Hiroshima University, Higashi-hiroshima 739-8528, Japan \\ ${ }^{2}$ Graduate School of Fisheries Sciences, Hokkaido University, Hakodate 041-8611, Japan \\ ${ }^{3}$ Kamiura Station of Japan Sea-Farming Association, Kamiura, Oita 879-2602, Japan \\ ${ }^{4}$ Hiroshima Prefectural Fisheries Experiment Station, Ondo, \\ Hiroshima 737-1207, Japan
}

(Received October 24, 2002)

\begin{abstract}
Japanese flounder Paralichthys olivaceus, farmed or wild, are often infected with aquabirnavirus (ABV) but the virus does not usually exhibit pathogenicity to the fish under usual experimental conditions. The present study investigated the experimental coinfection in flounder with $A B V$ and three flounder pathogens, i.e. viral hemorrhagic septicemia virus (VHSV), Edwardsiella tarda and Streptococcus iniae. When young flounder were injected with ABV $\left(10^{6.5}\right.$ $\mathrm{TCID}_{50} /$ fish) and subsequently (1 week later) injected with VHSV $\left(10^{6.7}\right.$ or $10^{4.7} \mathrm{TCID}_{50} /$ fish), higher survival rates were obtained in these flounder compared with those in fish infected with VHSV alone. In contrast, higher mortalities occurred in the flounder dually injected with $A B V\left(10^{6.8}\right.$ $\mathrm{TCID}_{50} /$ fish $)$ and $E$. tarda $\left(1.4 \times 10^{1} \mathrm{CFU} /\right.$ fish $)$ or $S$. iniae $\left(1.7 \times 10^{2} \mathrm{CFU} /\right.$ fish $)$ at a 1 week-interval than those in fish infected with bacteria alone. These results indicate that the primary ABV infection in flounder suppresses the secondary viral infection but facilitates the secondary bacterial infections.
\end{abstract}

Key words: coinfection, Paralichthys olivaceus, aquabirnavirus, viral hemorrhagic septicemia virus, Edwardsiella tarda, Streptococcus iniae, VHSV

A notable increase in the annual production of farmed Japanese flounder Paralichthys olivaceus has been realized over the years because of its high market value, abundance of suitable habitat for culture, and established seed production techniques. However, occurrence of infectious diseases attributed to pathogenic viruses and bacteria has often been encountered and thus remains as a major hurdle confronting productions.

Losses of young flounder due to aquabirnavirus (ABV) infection have been reported (Kusuda et al., 1989) but in recent years serious outbreaks of $A B V$ infection in farmed flounder have gradually declined. A recent survey conducted by Takano et al. (2001) on the distribution of fish pathogenic viruses revealed that 40.5 and $6.6 \%$ of

\footnotetext{
* Corresponding author

E-mail: fpath@ hiroshima-u.ac.jp
}

wild Japanese flounder were infected with $A B V$ and viral hemorrhagic septicemia virus (VHSV), respectively. However, the pathogenicity of isolated $A B V$ strains (identified as yellowtail ascites virus: YTAV, Leong et al., 2000) to young flounder was not exhibited by injection challenges while VHSV was proved to be highly pathogenic. VHSV has been recently implicated in mass mortalities of farmed flounder in the western part of Japan (Isshiki et al., 2001).

To date, only a handful of studies on viral interference between several piscine viruses have been demonstrated experimentally. Coinfections in Atlantic salmon Salmo salar with infectious pancreatic necrosis virus (IPNV) and infectious salmon anemia virus (ISAV) (Johansen and Sommer, 2001) and in young rainbow trout Oncorhynchus mykiss with IPNV and infectious haematopoetic necrosis virus (IHNV) or VHSV (de 
Kinkelin et al., 1992) have been reported.

Japanese flounder with on going ABV infection may also be subsequently infected with bacterial pathogens like Streptococcus iniae and Edwardsiella tarda, which are considered as the major causal agents of septicemia of cultured flounder and other fish species in Japan (Nakatsugawa, 1983; Kusuda et al., 1989; Muroga, 1997). Interactions between viruses and bacteria have not been well studied but recently Lee et al. (1999) reported on dual infection with IPNV and Vibrio carchariae in grouper, Epinephelus species. Groups of grouper dually infected with these 2 agents resulted in mortality rates significantly higher than those groups of fish with single infection. Additionally, the same trend has also been demonstrated experimentally in Atlantic salmon dually infected with IPNV and $V$. salmonicida (Johansen and Sommer, 2001).

To better define the role of $A B V$ in flounder, investigation on what consequences they can cause in the host fish (flounder) in concomitance with other viral and bacterial pathogens is essential. In the present study we demonstrated through experimental coinfections the effect of $A B V$ infection on the secondary VHSV, E. tarda or $S$. iniae infections in flounder.

\section{Materials and Methods}

\section{Viral strains}

Aquabirnavirus. An $\mathrm{ABV}$, designated as flounder birnavirus (FBV) strain, originally isolated from a diseased Japanese flounder (Nguyen et al., 1994), was used in a preliminary experiment and in the primary infection in 2 separate experiments. Rainbow trout gonad-2 (RTG-2) cell line maintained at $20^{\circ} \mathrm{C}$ in Eagle's minimum essential medium (MEM, Nissui) supplemented with $10 \%(V / V)$ fetal bovine serum $\left(=M_{E M}\right)$, $150 \mathrm{IU} / \mathrm{mL}$ penicillin $\mathrm{G}$ and $50 \mu \mathrm{g} / \mathrm{mL}$ kanamycin sulfate was used for virus propagation. The cells were infected with $A B V$ at a multiplicity of infection (MOI) of 0.01 and when the cytopathic effect (CPE) was extensive, the supernatant was harvested, concentrated by centrifugation, and stocked at $-80^{\circ} \mathrm{C}$ prior to use. The virus titer of the stock was determined by making viral dilutions in 96-well plates seeded with RTG-2 cells and counting the plate with CPE after incubation (Reed and Muench, 1938).

VHSV. The Obama25 strain of VHSV (Takano et al., 2001) was used at the $3^{\text {rd }}$ passage from the original isolation in ABV-VHSV coinfection experiment. VHSV was propagated (MOI: 0.01) in fathead minnow (FHM) cell line maintained in $\mathrm{MEM}_{10}$ supplemented with antibiotics. The harvested supernatant was processed and stocked following the protocol mentioned above prior to use.
Preparation of the bacterial inoculum

Streptococcus iniae (HS9507 from Japanese flounder) and Edwardsiella tarda (FK1051 from Japanese flounder) stored at $-80^{\circ} \mathrm{C}$ were inoculated on brain-heart infusion agar (BHIA) (Eiken) and heart infusion agar (HIA)(Difco), respectively, and incubated at $25^{\circ} \mathrm{C}$ for 48 h. Bacterial cells were harvested and resuspended in sterile phosphate buffered saline (PBS), then diluted to a desired concentration. The actual dose of $S$. iniae and $E$. tarda injected to fish were quantified by incubating serial dilutions of the bacteria on BHIA and HIA, respectively. The inoculum dose that induced about 30 to $50 \%$ mortality in our preliminary trials was used.

\section{Experimental fish}

Healthy Japanese flounder (average body weight $1.6 \mathrm{~g}$ for a preliminary experiment; $13.0 \mathrm{~g}$ for ABV-VHSV coinfection) reared at Hiroshima Prefectural Fisheries Experiment Station (HFES) were used in the preliminary experiment on ABV infectivity and ABV-VHSV coinfection experiment. In coinfection experiment involving $A B V$ and bacteria, healthy flounder with an average body weight of $7.2 \mathrm{~g}$, reared at the Kamiura Station of Japan Sea-Farming Association (JASFA) were used. Prior to infection experiment, fish were acclimatized to a laboratory condition for 10 days and maintained in a tank supplied with sand-filtered and flow-through seawater at $19 \pm 0.5^{\circ} \mathrm{C}$. Ten fish were randomly sampled from each group of acclimatized fish and sacrificed to ascertain the absence of ABV, VHSV, E. tarda and $S$. iniae by isolation using the above cell lines or media.

\section{Infection of flounder with $A B V$ alone}

In the preliminary experiment on the infectivity of $A B V$ in flounder, a total of 30 acclimatized flounder were intramuscularly (i.m.) injected with $A B V$ at a dose of $10^{6.5}$ $\mathrm{TCID}_{50} /$ fish and maintained in $80 \mathrm{~L}$ aquarium at $19 \pm$ $0.5^{\circ} \mathrm{C}$. At 1,2 and $3 \mathrm{wk}, \mathrm{ABV}$ titers in the kidney of each 10 randomly sampled fish were determined by using RTG-2 cells.

\section{Coinfection of flounder with ABV and VHSV}

A total of 70 acclimatized flounder were randomly divided into 2 groups. The first group comprised of 40 fish were i.m. injected with $\mathrm{ABV}\left(10^{6.5} \mathrm{TCID}_{50} / \mathrm{fish}\right)$ and were randomly assigned into 3 separate subgroups (A:15, B:15, C:10 fish) at a density of 15 or $10 \mathrm{fish} / 80 \mathrm{~L}$ aquarium. The remaining 30 flounder were i.m. injected with $\mathrm{MEM}_{10}$ and randomly separated into 3 subgroups: $D, E$ and $F$ (each 10 fish). Five fish in the groups $A$ and $B$ were randomly taken 1 wk later for $A B V$ titration prior to secondary VHSV infection.

At 1 wk post-ABV infection, subgroups $A$ and $D$, and subgroups $B$ and $E$ were i.m. injected with $10^{6.7}$ (high dose) and $10^{4.7}$ (low dose) TCID 50 /fish of VHSV, respectively. Subgroups $C$ and $F$ were given $M E M_{10}$ to 
serve as controls. Infected flounder were kept under similar conditions as before at water temperature of $19 \pm$ $0.5^{\circ} \mathrm{C}$ and mortalities were recorded daily for $2 \mathrm{wk}$.

Coinfection of flounder with $A B V$ and $\mathrm{S}$. iniae or $\mathrm{E}$. tarda The secondary bacterial challenges were conducted in 2 separate occasions, i.e. at 1 and 3 wk post-ABV infection. A total of 150 Japanese flounder were i.m. injected with $\mathrm{ABV}\left(10^{6.8} \mathrm{TCID}_{50} / \mathrm{fish}\right)$ and randomly divided into 6 groups (each 25 fish) designated as $A, B$, $C, D, E$, and $F$ at a density of 25 fish/100 $L$ aquarium. The same numbers of flounder were i.m. injected with $\mathrm{MEM}_{10}$ and randomly divided into 6 groups designated as $G, H, I, J, K$, and L. Twenty-five extra fish injected with the same dose of $A B V$ were placed in another tank (100 L) and 10 fish (5 fish at $2 \mathrm{wk}$ ) were randomly taken for virus titration at 1,2 and 3 wk post infection prior to the bacterial infection.

At 1 wk post-ABV infection, groups $A$ and $G$ were i.m. injected with $S$. iniae at a dose of $1.7 \times 10^{2} \mathrm{CFU} /$ fish and groups $B$ and $H$ with $E$. tarda at a dose of $1.4 \times$ $10^{1} \mathrm{CFU} /$ fish. Groups $\mathrm{C}$ and I were injected with PBS to serve as controls. After the injection, fish were returned back to their respective aquaria and maintained in the same condition as before.

At 3 wk post $A B V$-infection, groups $D$ and $J$ were i.m. injected with $S$. iniae $\left(1.8 \times 10^{2} \mathrm{CFU} / \mathrm{fish}\right)$ while groups $\mathrm{E}$ and $\mathrm{K}$ were i.m. injected with $\mathrm{E}$. tarda $(1.0 \times$ $10^{1} \mathrm{CFU} /$ fish). Groups $\mathrm{F}$ and $\mathrm{L}$ were injected with PBS and served as controls. Fish mortalities were recorded daily for $2 \mathrm{wk}$.

\section{Virological examination}

VHSV infective titers in the pooled organ tissues (spleen, head kidney, brain, and heart) of all dead and surviving coinfected samples were quantified by inoculating in FHM cells after treated with a diluted antiserum (1:100) against YTAV. Pooled organ tissues of dead and surviving fish solely infected with VHSV were titrated in FHM cell line without YTAV-neutralizing process. Since RTG-2 cell line is not highly susceptible to flounder isolates of VHSV (Mori et al., 2002), pooled organ tissues of all coinfected fish, dead or surviving, were directly titrated in RTG-2 to quantify ABV titers. CPE produced in FHM or RTG-2 cell line was confirmed as VHSV or ABV by an indirect fluorescent antibody technique using a diluted antiserum against VHSV (1:100) or YTAV (1:500).

\section{Bacteriological examination}

To confirm bacterial infection in dead fish with single and dual infections, portions of the kidney and brain of each fish were aseptically excised and streaked on BHIA (for S. iniae) or HIA (for E. tarda) and incubated at $25^{\circ} \mathrm{C}$ for $48 \mathrm{~h}$. The isolated bacteria were confirmed as $E$. tarda by further streaking on Salmonella-Shigella agar
(Eiken) for the production of black pigment or as $S$. iniae by subjecting to Gram-staining. All survivors collected at the termination of the experiment were likewise examined in the same manner.

In vitro viral interference assay

The interference between ABV and VHSV in vitro was examined following a modified method of Chinchar et al. (1998). Briefly, at 0, 6, 12 or $24 \mathrm{~h}$ prior to VHSV infection (MOI: 0.2), FHM cells seeded in 24-well plates were exposed to ABV with different MOls: 1, 0.1, 0.01, and 0.001 . Separate wells inoculated only with ABV or VHSV were used as controls. After $48 \mathrm{~h}$ of incubation at $20^{\circ} \mathrm{C}$, a portion of the supernatant from each well was taken and VHSV titers in the supernatants of the coinfected groups were quantified following the protocol mentioned above.

\section{Statistical analyses}

Differences in cumulative mortalities between groups of fish were compared using the Fisher's exact test (ABV and VHSV) or the $\chi^{2}$ test ( $\mathrm{ABV}$ and bacteria) at $5 \%$ confidence level.

\section{Results}

\section{$A B V$ infectivity in flounder}

$A B V$ was detected with titers ranging $10^{3.0} \sim 10^{5.5}$ $\mathrm{TCID}_{50} / \mathrm{g}$ from all 10 flounder examined at $1 \mathrm{wk}$ post infection, while at 2 wk post infection only 5 out of 10 fish examined had ABV titers ranging $10^{3.8} \sim 10^{4.3} \mathrm{TCID}_{50} /$ g. At 3 wk post infection, ABV could only be detected in 3 out of 10 fish examined, with $A B V$ titers ranging $10^{3.1} \sim 10^{3.8} \mathrm{TCID}_{50} / \mathrm{g}$. No abnormal signs were noted in these $A B V$-infected fish.

\section{Mortality of flounder in coinfection experiments}

ABV and VHSV : ABV titers in the kidney of 10 flounder quantified prior to secondary VHSV infection ranged $10^{2.8} \sim 10^{4.3} \mathrm{TCID}_{50} / \mathrm{g}$ at 1 wk post $\mathrm{ABV}$-infection.

$A B V$-infected Japanese flounder that were sequentially infected with $\mathrm{VHSV}$ at $1 \mathrm{wk}$ post-ABV infection resulted in mortality rates $(0 \%)$ significantly lower $(p<0.05)$ than those fish solely infected with high $(100 \%)$ and low $(60 \%)$ doses of VHSV (Fig. 1a and b). No mortality or abnormal condition was noted in ABV alone or mock infected fish. VHSV titers quantified in the pooled organ tissues of dead fish (10 fish) singly infected with high dose VHSV ranged from $10^{6.3}$ to $10^{8.8} \mathrm{TCID}_{50} / \mathrm{g}$ (mean: $10^{8.1} \mathrm{TCID}_{50} / \mathrm{g}$ ) while those of the fish (6 fish) infected with low dose VHSV ranged from $10^{6.3}$ to $10^{7.8}$ $\mathrm{TCID}_{50} / \mathrm{g}$ (mean: $10^{7.2} \mathrm{TCID}_{50} / \mathrm{g}$ ). ABV was not detected in the coinfected flounder at the termination of the experiment except for 2 samples. Dead fish singly infected with VHSV manifested behavioral changes including anorexia and lethargy and external signs like 
a) ABV + VHSV (High Dose)

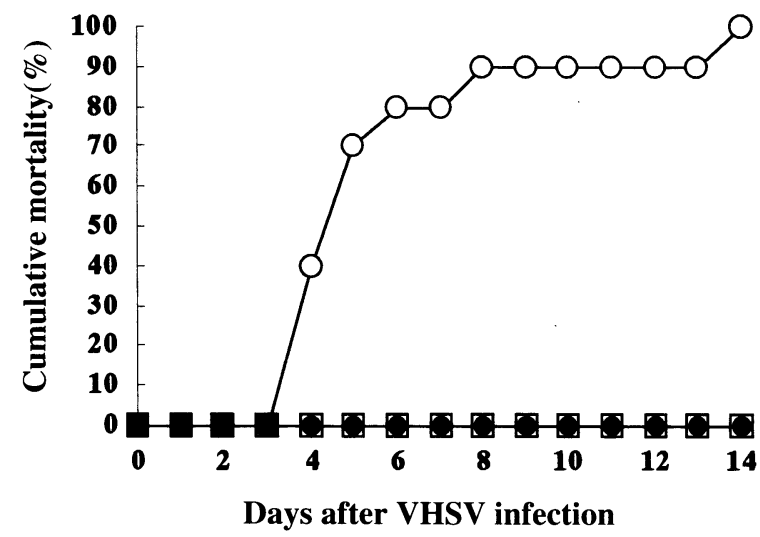

b) ABV + VHSV (Low Dose)

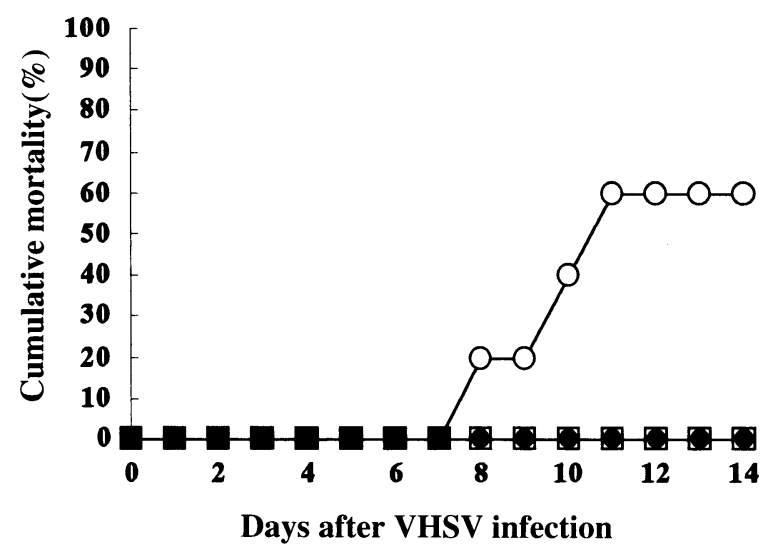

Fig. 1. Cumulative mortalities in groups of Japanese flounder intramuscularly injected with (a) high and (b) low doses of VHSV at 1 wk post-ABV infection. 0 : A (ABV + VHSV high dose) or $\mathrm{B}$ (ABV + VHSV low dose); $\mathrm{O}$ : D $\left(M M_{10}+\right.$ VHSV high dose) or E $\left(M^{\prime} M_{10}+\right.$ VHSV low dose); $\square: C\left(A B V+M^{2} M_{10}\right)$ or $F\left(M_{10}+M_{10} M_{10}\right)$. See text for fish groups $A$ to $F$.

dark coloration of the body, distended abdomen and hemorrhagic fins. Dissection of these fish samples revealed the presence of ascitic fluid in the peritoneal cavity, swollen kidney and spleen, and hemorrhage in the muscle and/or viscera. In contrast, coinfected fish did not show any pathological signs and VHSV was not detected in the survivors except for the 3 samples with virus titers ranging $10^{2.3} \sim 10^{3.3} \mathrm{TCID}_{50} / \mathrm{g}$.

$A B V$ and bacteria : Cumulative mortalities of flounder secondarily infected with $S$. iniae or $E$. tarda at 1 wk post-ABV infection are shown in Fig. $2 \mathrm{a}$ and $\mathrm{b}$. Fish infected with $A B V$ followed by $S$. iniae had a mortality rate of $84 \%$, significantly higher $(p<0.05)$ than those infected with $S$. iniae alone (52\%). Similarly, significantly more fish dually infected with ABV and E. tarda died $(76 \%)$ than those infected with E. tarda alone (44\%) $(p<0.05)$. No mortalities were recorded in the mock and ABV singly infected groups. Coinfected fish that died within few days after $S$. iniae infection had slight to mod- a) $S$. iniae

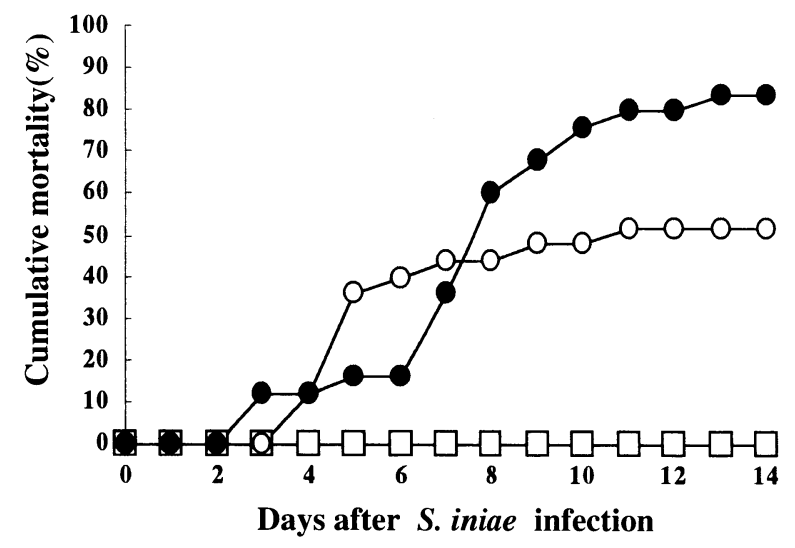

b) E. tarda

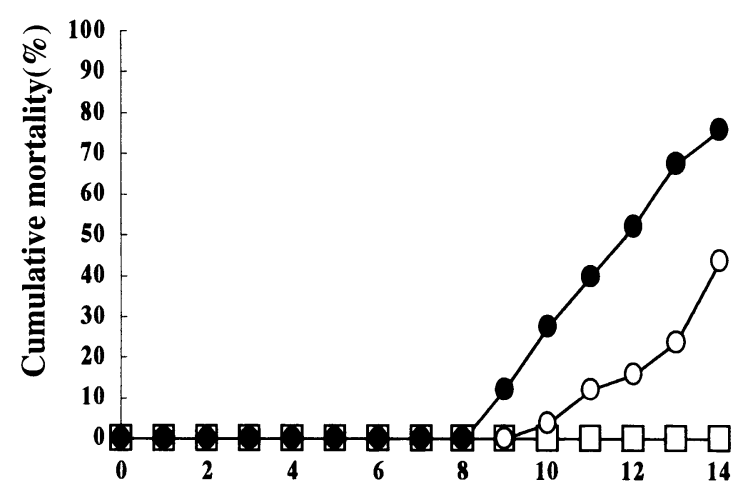

Days after E. tarda infection

Fig. 2. Cumulative mortalities of Japanese flounder intramuscularly injected with (a) $S$. iniae or (b) $E$. tarda at 1 wk post-ABV infection. $\mathrm{O}$ : $\mathrm{A}(\mathrm{ABV}+\mathrm{S}$. iniae) or $\mathrm{B}(\mathrm{ABV}$ + E. tarda); $O: \mathrm{G}\left(\mathrm{MEM}_{10}+\right.$ S. iniae $)$ or $\mathrm{H}\left(\mathrm{MEM}_{10}+E\right.$. tarda); $\square: C($ ABV + PBS) or I (MEM $10+$ PBS). See text for fish groups $A$ to $I$.

erate hemorrhage while those that died later had developed furuncle-like lesion with hemorrhagic periphery at injection site, hemorrhage in the body, ascites, swollen kidney and spleen, and exophthalmia. Pure cultures of $S$. iniae were recovered from the kidney and brain of dead fish with single and dual infections. Mortalities of fish injected with E. tarda commenced a week later after infection but the progression of disease signs like abdominal distention due to ascites, development of furuncle-like lesion with hemorrhagic periphery at injection site, and moderate to severe swelling of the spleen and kidney occurred early in the coinfected group. Pure cultures of $E$. tarda were recovered from all dead and surviving fish with single and double infections. On the contrary, no significant differences in mortalities were obtained between these groups of flounder with single and double infections after they were injected with either $S$. iniae or $E$. tarda at 3 wk post-ABV infection (Fig. $3 a$ and b). 
a) S. iniae

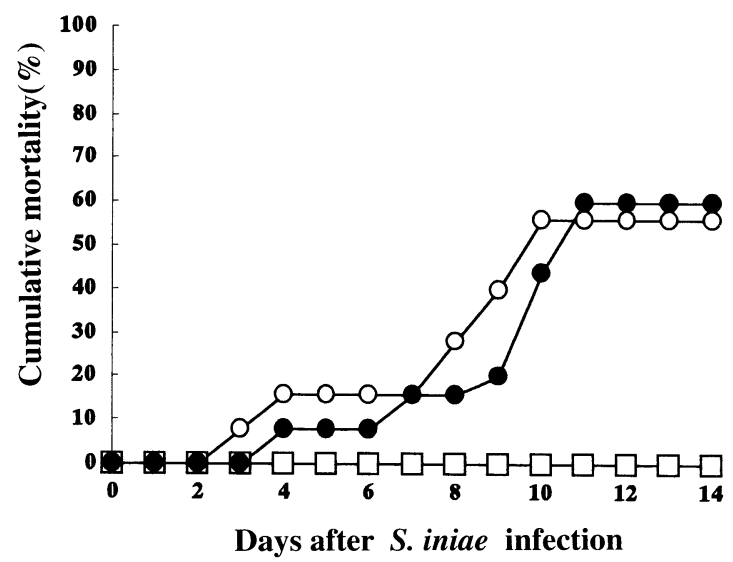

b) E. tarda

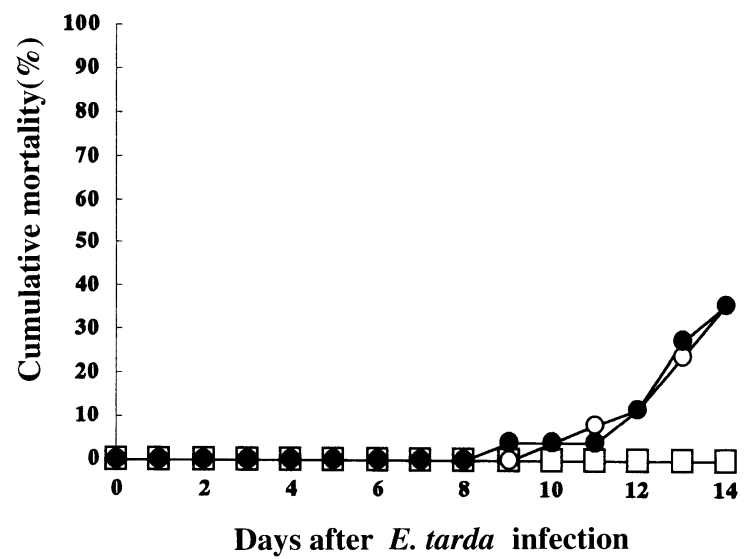

Fig. 3. Cumulative mortalities of Japanese flounder intramuscularly injected with (a) S. iniae or (b) E. tarda at 3 wk post-ABV infection. $\mathrm{O}$ : $(\mathrm{ABV}+\mathrm{S}$. iniae) or $\mathrm{E}(\mathrm{ABV}$ + E. tarda); $\mathrm{O}: \mathrm{J}\left(\mathrm{MEM}_{10}+\right.$ S. iniae $)$ or $\mathrm{K}\left(\mathrm{MEM}_{10}+E\right.$. tarda); $\square: F(A B V+$ PBS) or L (MEM $10+$ PBS). See text for fish groups $D$ to $F$ and $J$ to $L$.

$A B V$ titers quantified in the head kidney of flounder at 1 and 2 wk post infection ranged $10^{5.3} \sim 10^{7.5}$ (positive/ tested: $10 / 10$ ) and $10^{3.4} \sim 10^{5.6} \mathrm{TCID}_{50} / \mathrm{g}(5 / 5)$, respectively. Furthermore, ABV titers of dead fish with secondary $S$. iniae infection ranged $10^{3.1} \sim 10^{6.8} \mathrm{TCID}_{50} / \mathrm{g}$ while those with secondary $E$. tarda infection ranged $10^{3.1}$, $10^{7.2} \mathrm{TCID}_{50} / \mathrm{g}$. ABV was detected from 4 out of 10 fish tested $\left(10^{3.4} \sim 10^{3.9} \mathrm{TCID}_{50} /\right.$ fish) at $3 \mathrm{wk}$ post-ABV infection, but it was not detected in dead or surviving fish secondarily infected with bacteria at this period.

\section{In vitro viral interference assay}

Preinfection of FHM cells with ABV followed by VHSV at various time intervals failed to completely inhibit the production of CPE by VHSV (Fig. 4). Simultaneous coinfection of FHM cells at $\mathrm{O} h$ with VHSV (MOI: 0.2) and $\mathrm{ABV}$ with a lower $\mathrm{MOI}(0.001)$ resulted in the production of CPE attributed purely to VHSV. It seemed that a $\mathrm{MOI}-d e p e n d e n t$ factor could be responsible for the inter-

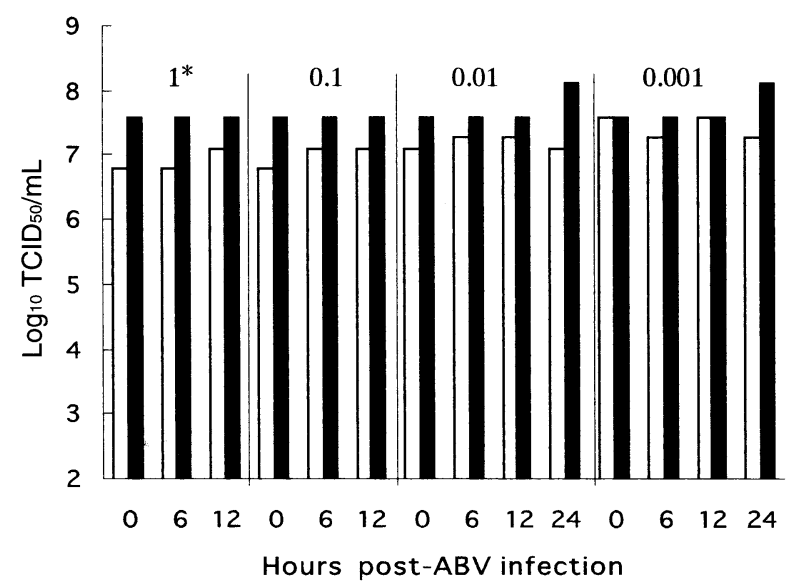

Fig. 4. VHSV titers in the supernatants of FHM cells at $48 \mathrm{~h}$ post-VHSV infection previously infected with $A B V$ at different MOls* and time points or with none (control). $\square$ : VHSV titer (coinfected); $\mathbf{\square}$ : VHSV titer (control).

ference because slight reductions ( $\leq 1 \log _{10}$ of $\mathrm{TCID}_{50}$ / $\mathrm{mL}$ ) of VHSV titers were attained when the MOI of ABV was higher than that of VHSV or by allowing ABV to replicate first in FHM cells for $24 \mathrm{~h}$ prior to VHSV inoculation. FHM cells infected with $\mathrm{ABV}$ with $\mathrm{MOI}$ of 1 and 0.1 produced massive CPE at $24 \mathrm{~h}$ post infection hence subsequent infection with VHSV was not done.

\section{Discussion}

In the present study, the effects of preceding $A B V$ infection on secondary VHSV, $S$. iniae, or $E$. tarda infections in flounder were demonstrated through experimental infections. When groups of fish with preceding $A B V$ infection were sequentially injected with VHSV at 1 wk post-ABV infection, suppression of the disease inflicted by the latter agent was observed. Our results indicate that prior $A B V$ infection could create a resistant state in flounder to subsequent VHSV infection.

Viral interference has been reported following infections of fish with heterologous viruses. For example, de Kinkelin et al. (1992) obtained higher survival rates in rainbow trout with prior IPNV infection that were sequentially infected with either VHSV or IHNV. Similarly, Hedrick et al. (1994) observed that rainbow trout alevins pre-exposed to avirulent cutthroat trout virus (CTV) were protected from secondary IHNV infection and the protection was registered for up to 4 weeks following CTV exposure. Very recently, Johansen and Sommer (2001) showed that the on going IPNV infection in Atlantic salmon could provide protection against a secondary ISAV infection. However, these phenomena have scarcely been reported in marine fish.

In these aforesaid studies the mechanisms behind the induction of resistance were poorly understood and conclusions were based on speculations like the production of interferon (IFN) and/or stimulation of nonspecific 
cellular factors including macrophage or cytotoxic cell activity. It is known that fish produce IFN in response to viral infections and the kinetics of IFN production has been correlated to the duration of the virus replication (de Kinkelin and Dorson, 1973; Renault et al., 1991; de Kinkelin et al., 1992; Dorson et al., 1992). Supported by these available data, we thought that the suppression of VHSV infection in this study must also be due to an antiviral-like substance(s), most likely IFN, which could have been produced during the logarithmic stage of $A B V$ replication in flounder. This speculation is further supported by our finding that VHSV was not detected in the coinfected survivors but was detected in fish with single VHSV infection. The interference assay between ABV and VHSV failed to simulate the above phenomenon in vitro, although slight reductions of VHSV titers were noted in some test (coinfected) groups.

Our results on coinfection between ABV and bacteria in vivo clearly demonstrated that $A B V$ plays a significant role in developing of a secondary bacterial infection. When groups of fish were subjected to second infection with $S$. iniae or $E$. tarda at 1 wk post-ABV infection, more fish died in the coinfected group than in those groups of fish solely infected with bacteria. However, when groups of fish were subsequently infected with bacteria at 3 wk post-ABV infection, no significant differences in mortalities were noted. These results indicate that active replication of $A B V$ in flounder that occurs during the early stage of infection is an important predisposing factor for fish to become more susceptible to a secondary bacterial infection.

The mechanism(s) behind the interactions between $A B V$ and bacteria in the present study is not known but in nature many virus infections are accompanied by general immunosuppression that may affect the phagocytic activity of fish leukocytes. For example, a significant decrease in mitogenic response and non-specific cytotoxicity has been demonstrated in the head kidney leukocytes from rainbow trout experimentally infected with IPNV (Tate et al., 1990). The active replication of ABV in flounder could have resulted in a transient immunosuppression that lowered the bactericidal activity of flounder phagocytes. This is one logical reason why more fish with subsequent bacterial infection died. Further studies on the interactions between ABV and bacteria at the cellular level should be pursued to better understand the pathogenesis of the disease.

The present study provides new information on the role $A B V$ in Japanese flounder in concomitance with other pathogens like virus or bacteria. Additionally, our results give more weight to our hypothesis that the high prevalence of $A B V$ infection in a flounder population may limit the replication and horizontal transmission of VHSV but facilitate the detrimental effects of the secondary bacterial infections.

\section{Acknowledgments}

This study was financially supported by JASFA and the Ministry of Education, Science, Sports and Culture of Japan. We gratefully thank some staff of HFES and JASFA for their kind assistance during the experiment.

\section{References}

Chinchar, V. G., O. Logue, A. Antao and G. D. Chinchar (1998): Channel catfish reovirus (CRV) inhibits replication of channel catfish herpesvirus (CCV) by two distinct mechanisms: viral interference and induction of an anti-viral factor. Dis. Aquat. Org., 33, 77-85.

de Kinkelin, P. and M. Dorson (1973): Interferon production in rainbow trout (Salmo gairdneri) experimentally infected with Egtved virus. J. Gen. Virol., 19, 125-127.

de Kinkelin, P., M. Dorson and T. Renault (1992): Interferon and viral interference in viruses of salmonid fish. In: "Salmonid Diseases, Proceedings of the OJI international symposium on salmonid fish", (ed. by T. Kimura), Hokkaido University Press, Sapporo, pp. 241-249.

Dorson, M., P. de Kinkelin and T. Torchy (1992): Interferon synthesis in rainbow trout fry following infection with infectious pancreatic necrosis virus. Fish Shellfish Immunol., 2, 311-313.

Hedrick, R. P., S. E. La Patra, S. Yun, K. A. Lauda, G. R. Jones, J. L. Congleton and P. de Kinkelin (1994): Induction of protection from infectious hematopoietic necrosis virus in rainbow trout Oncorhynchus mykiss by pre-exposure to the avirulent cutthroat trout virus (CTV). Dis. Aquat. Org., 20, 118-124.

Isshiki, T., T. Nishizawa, T. Kobayashi, T. Nagano and T. Miyazaki (2001): An outbreak of VHSV (viral hemorrhagic septicemia virus) infection in farmed Japanese flounder Paralichthys olivaceus in Japan. Dis. Aquat. Org., 47, 8799.

Johansen, L. and A. Sommer (2001): Infectious pancreatic necrosis virus infection in Atlantic salmon Salmo salar postsmolts affects the outcome of secondary infections with infectious salmon anemia virus or Vibrio salmonicida. Dis. Aquat. Org., 47, 109-117.

Kusuda, R., K. Kado, Y. Takeuchi and K. Kawai (1989): Characteristics of 2 virus strains isolated from young Japanese flounder Paralichthys olivaceus. Suisanzoshoku, 37, 115-120. (In Japanese with English abstract)

Lee, K. K., T. I. Yang, P. C. Liu, J. L. Wu and Y. L. Hsu (1999): Dual challenges of infectious pancreatic necrosis virus and Vibrio carchariae in the grouper Epinephelus sp. Virus Res., 63, 131-134.

Leong, J.C., D. Brown, P. Dobos, F.S.B. Kibenge, J.E. Ludert, H. Muller, E. Mundt and B. Nicholson (2000): Family Birnaviridae, In "Virus Taxonomy, Seventh Report of the International Committee on Taxonomy of Viruses" (ed. by M. H. V. van Regenmortel, C. M. Fauquet, D. H. L. Bishop, E. B. Carstens, M. K. Estes, S. M. Lemon, J. Maniloff, M. A. Mayo, D.J. McGeoch, C.R. Pringle and R.B. Wickner). Academic Press, San Diego, pp. 481-490.

Mori, K., H. lida, T. Nishizawa, M. Arimoto, K. Nakajima and K. Muroga (2002): Properties of viral hemorrhagic septicemia virus (VHSV) isolated from Japanese flounder Paralichthys olivaceus. Fish Pathol., 37, 169-174.

Muroga, K. (1997): Recent advances in infectious diseases of marine fish with particular reference to the case in Japan. In: "Diseases in Asian aquaculture III", (ed. by T. W. Flegel 
and I. H. MacRae), Fish Health Section, Asian Fish. Soc. Manila, pp. 21-31.

Nakatsugawa, T. (1983): A streptococcal disease of cultured flounder. Fish Pathol., 17, 281-285. (In Japanese with English abstract)

Nguyen, H. D., T. Mekuchi, K. Imura, T. Nakai, T. Nishizawa and K. Muroga (1994): Occurrence of viral nervous necrosis (VNN) in hatchery-reared juvenile Japanese flounder Paralichthys olivaceus. Fisheries Sci., 60, 551-554.

Reed, J. L. and H Muench (1938): A simple method for estimating fifty percent end points. Am. J. Hyg., 27, 493-497.

Renault, T., C. Torchy and P. de Kinkelin (1991): Spectrophoto- metric method for titration of trout interferon, and its application to rainbow trout fry experimentally infected with viral haemorrhagic septicaemia virus. Dis Aquat. Org., 10, 2329.

Takano, R., K. Mori, T. Nishizawa, M. Arimoto and K. Muroga (2001): Isolation of viruses from wild Japanese flounder Paralichthys olivaceus. Fish Pathol., 36, 153-160.

Tate, H., H. Kodama and H. Izawa (1990): Immunosuppressive effect of infectious pancreatic necrosis virus on rainbow trout (Oncorhynchus mykiss). Jpn. J. Vet. Sci., 52, 931937. 